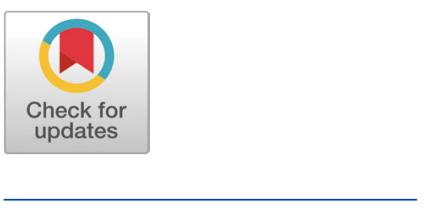

Received: Mar 6, 2020

Revised: Mar 18, 2020

Accepted: Mar 20, 2020

\# These authors contributed equally to this work.

*Corresponding author Hyeun Bum Kim

Department of Animal Resource and

Science, Dankook University,

Cheonan 31116, Korea.

Tel: +82-41-550-3652

E-mail: hbkim@dankook.ac.kr

Jin $\mathrm{Ho}$ Cho

Division of Food and Animal Science, Chungbuk National University,

Cheongju 28644, Korea.

Tel: +82-43-261-2544

E-mail: jinhcho@chungbuk.ac.kr

Copyright $\odot 2020$ Korean Society of Animal Sciences and Technology.

This is an Open Access article distributed under the terms of the Creative Commons Attribution Non-Commercial License (http:// creativecommons.org/licenses/by$\mathrm{nc} / 4.0 /$ ) which permits unrestricted non-commercial use, distribution, and reproduction in any medium, provided the original work is properly cited.

ORCID

Han Jin Oh

https://orcid.org/0000-0002-3396-483X Min Ho Song

https://orcid.org/0000-0002-4515-5212

Won Yun

https://orcid.org/0000-0002-1835-2640

\section{Effects of replacing soybean meal with perilla seed meal on growth performance, and meat quality of broilers}

\author{
Han Jin Oh" ${ }^{1 \#}$, Min Ho Song ${ }^{2 \#}$, Won Yun 1 , Ji Hwan Lee ${ }^{1}$, Ji Seon An", Yong Ju Kim", \\ Gok Mi Kim ${ }^{3}$, Hyeun Bum $\mathrm{Kim}^{4 *}$ and Jin Ho Cho ${ }^{1 *}$ \\ ${ }^{1}$ Division of Food and Animal Science, Chungbuk National University, Cheongju 28644, Korea \\ ${ }^{2}$ Division of Animal and Dairy Science, Chungnam National University, Daejeon 34134, Korea \\ ${ }^{3}$ Department of Beauty Art, Yonam College, Cheonan 31005, Korea \\ ${ }^{4}$ Department of Animal Resource and Science, Dankook University, Cheonan 31116, Korea
}

\section{Abstract}

The purpose of this study was to evaluate effects of replacing soybean meal with perilla seed meal (PSM) on growth performance, proximate composition of meat, meat quality, and fatty acids composition of meat in broilers. A total of 60 one-day-old chicks of ROSS 308 (initial body weight of $44.8 \pm 0.4 \mathrm{~g}$ ) were randomly allotted to four treatment groups (15 replicate cages with 1 broilers per cage) in a period of 5 weeks. Dietary treatments included control (CON) basal diet (corn-soybean meal-based diets) and test diets in which PSM was included at $0.5 \%$ (T1), $1 \%(\mathrm{~T} 2)$, or $2 \%$ (T3) to gradually replace soybean meal. At the end of experiment, all broilers were slaughtered for collecting breast and thigh meat. At 5 weeks, T2 and T3 treatment groups had higher $(p<0.05)$ body weights than CON and T1 treatment groups. Weight gain was increased $(p<0.05)$ in T2 and T3 treatment groups. Feed intake was decreased $(p<0.05)$ in T3 treatment group. Broilers in T2 treatment group had lower ( $p$ $<0.05$ ) feed conversion ratio than those in other treatment groups. In proximate composition of breast meat, there was no significant $(p>0.05)$ difference in moisture and ash. Fat composition of breast meat was significantly $(p<0.05)$ increased in T2 and T3 treatment groups. Regarding meat quality, broilers fed T3 diet had higher $(p<0.05)$ water holding capacity than those fed other diets. Regarding fatty acids composition of thigh meat, broilers fed T3 diet had higher $(p<0.05)$ linolenic acid than those fed other diets. In conclusion, soybean meal replaced by $2 \%$ perilla seed meal in broiler diet can improve growth performance, meat quality, and fatty acids composition of thigh meat in broilers. Perilla seed meal can be a lot of potential alternatives feedstuff for soybean meal in this study.

Keywords: Feed stuff, Perilla seed meal, Growth performance, Meat quality, Fatty acids composition 
Ji Hwan Lee

https://orcid.org/0000-0001-8161-4853

Ji Seon An

https://orcid.org/0000-0002-9205-8095

Yong Ju Kim

https://orcid.org/0000-0002-0960-0884

Gok Mi Kim

https://orcid.org/0000-0003-1053-4535

Hyeun Bum Kim

https://orcid.org/0000-0003-1366-6090

Jin Ho Cho

https://orcid.org/0000-0001-7151-0778

Competing interests

The authors declare no conflict of interest.

Funding sources

This research was supported by 'EUMSEONG

PERILLA CONVERGENCE AGENCY' in

Eumseong county.

Acknowledgements

Not applicable.

Availability of data and material

Upon reasonable request, the datasets

of this study can be available from the

corresponding author.

Authors' contributions

Conceptualization: Oh HJ, Song MH, Kim HB, Cho JH.

Data curation: Oh HJ, Song MH.

Formal analysis: $\mathrm{Oh} \mathrm{HJ}$, Song $\mathrm{MH}$.

Investigation: Yun W, Lee JH, An JS, Kim YJ, Kim GM

Writing - original draft: $\mathrm{Oh} \mathrm{HJ}$, Song $\mathrm{MH}$. Writing - review \& editing: Kim HB, Cho JH.

Ethics approval and consent to participate The Animal Care and Use Committee of Chungbuk National University approved all the experimental protocols used in the current study.

\section{INTRODUCTION}

Chicken meat has lower cholesterol and saturated fatty acid content than other meats, but there have been many attempts to produce beneficial fatty acids for human body and produce chicken with less cholesterol and saturated fatty acids. In particular, as the effect of omega-3-unsaturated fatty acids on lowering blood lipid concentration and reducing the incidence of circulatory diseases have been reported [1,2], many researchers have been a great interest in the production of livestock containing omega-3-polysaturated fatty acids. Although attempts to lower cholesterol levels in eggs and meat have not been successful [3], however, many studies reported that the fatty acids composition in these poultry products is influenced by the dietary feed such as fish oil and fish meal $[4,5]$, sesame oil and sesame meal [6,7]. For this reason, we consider feedstuff rich in omega-3-unsaturated fatty acids.

Perilla seed meal (PSM) is known to be enriched in compositions of omega-3 polysaturated fatty acids and bioactive compounds such as phytic acid, polysaccharides, phenolic compounds, and protein as a by-product made after extracting oil from perilla seeds [8]. The rich nutrient content and the use of by-product have received much attention recently to increase profitability $[9,10]$. In our analysis, PSM has been shown to be a potential protein (39.01\%) source of feed. The use of PSM as feedstuff can be an alternative to soybean meal whose cost has increased in recent years [11]. However, studies on the use of PSM as a feedstuff in livestock are insufficient. Therefore, the aim of this experiment was to evaluate effects of replacing soybean meal with perilla seed meal on growth performance, and meat quality in ROSS 308 broilers.

\section{MATERIALS AND METHODS}

Experimental protocols describing the management and care of animals were reviewed and approved by the Animal Care and Use Committee of Chungbuk National University.

\section{Animals, facilities, and dietary treatments}

A total of 60 healthy mixed sex 1-day-old ROSS 308 broilers with an initial body weight (BW) of $44.8 \pm 0.4 \mathrm{~g}$ were used in a 5 -week experiment. Broilers were randomly blocked based on their initial BWs to four treatment groups. Each treatment group had fifteen replicate cages (1 broilers per cage). Water and feed were available ad libitum. The experiment was divided into two periods: a starter period ( 0 to 2 weeks of age) and a finishing period ( 2 to 5 weeks of age). Table 1 shows nutrient compositions of the perilla seed meal used in this study. Dietary treatments included a control (CON) corn-soybean meal based diets (basal diet) and three test diets in which perilla seed meal (Table 1) was included at $0.5 \%$ (T1), $1 \%$ (T2), and $2 \%$ (T3) to gradually replace soybean meal (Tables 2 and 3). To meet amino acid requirements, diets in the finishing period were supplemented with L-lysine and corn gluten meal. All diets were formulated to meet or exceed National Research council (NRC) [12] nutrient requirements for poultry.

\section{Sampling and measurements}

Individual broilers' BWs were recorded at the end of weeks 0,2 , and 5, and feed intake were recorded every day to determine weight gain (WG), feed intake (FI), and feed conversion ratio (FCR). All broilers of each treatment were selected at the end of the $5^{\text {th }}$ week to collect breast and leg meat. Aponeuroses and skin were removed from breast and leg samples. They were then homogenized and submitted for proximate analysis. Moisture, fat, and ash contents were analyzed in triplicate. All analyses were carried out according to AOAC method [13]. Water holding capacity (WHC) was 
Table 1. Chemical composition of perilla seed meal

\begin{tabular}{lc}
\hline \multicolumn{1}{c}{ Items } & Content \\
\hline Ingredients (\%) & 7.84 \\
Moisture & 39.01 \\
Crude protein & 7.31 \\
Crude fat & 5.92 \\
Ash & 0.50 \\
Calcium & 1.37 \\
Phosphate & \\
Calculated composition & 2,820 \\
Metabolizable energy (MJ/kg) & 2.39 \\
Lysine (\%) & 1.14 \\
Methionine (\%) & 0.43 \\
Cysteine (\%) &
\end{tabular}

determined following the method of Laakkonenen et al. [14]. The $\mathrm{pH}$ values of breast meat were determined by using glass-eletrode $\mathrm{pH}$ meter (WTH Measurement System, Ft. Myers, Florida, FL, USA). Drip loss, cooking loss, and shear force after cooking were measured according to the guide of Sirri et al. [15]. The breast meat color value was analyzed by using a reflectance spectrometry chroma meter (Yasuda Seiko, Minolta,Japan) to measure lightness $\left(\mathrm{L}^{*}\right)$, redness $\left(\mathrm{a}^{*}\right)$ and yellowness $\left(\mathrm{b}^{*}\right)$.

Table 2. Ingredient composition of starter diets (0-2 weeks)

\begin{tabular}{|c|c|c|c|c|}
\hline Items & CON & T1 & T2 & T3 \\
\hline \multicolumn{5}{|l|}{ Ingredients (\%) } \\
\hline Corn & 46.16 & 45.66 & 45.15 & 44.50 \\
\hline Soybean meal, $48 \% \mathrm{CP}$ & 36.04 & 35.54 & 34.05 & 34.02 \\
\hline Wheat & 10.00 & 10.00 & 10.00 & 10.00 \\
\hline Wheat bran & 4.50 & 5.00 & 5.50 & 6.00 \\
\hline Perilla seed meal & 0.00 & 0.50 & 1.00 & 2.00 \\
\hline DL-Methionine & 0.20 & 0.20 & 0.20 & 0.20 \\
\hline Choline chloride & 0.20 & 0.20 & 0.20 & 0.20 \\
\hline Limestone & 1.00 & 1.00 & 1.00 & 1.00 \\
\hline Dicalcium phosphate & 1.50 & 1.50 & 1.50 & 1.50 \\
\hline Salt & 0.20 & 0.20 & 0.20 & 0.20 \\
\hline Vitamin premix ${ }^{1)}$ & 0.10 & 0.10 & 0.10 & 0.10 \\
\hline Mineral premix $x^{2)}$ & 0.10 & 0.10 & 0.10 & 0.10 \\
\hline \multicolumn{5}{|l|}{ Calculated composition } \\
\hline ME (kcal/kg) & 3,220 & 3,221 & 3,213 & 3,215 \\
\hline $\mathrm{CP}(\%)$ & 23.00 & 23.00 & 23.00 & 23.00 \\
\hline Lysine (\%) & 1.275 & 1.274 & 1.273 & 1.273 \\
\hline Methionine (\%) & 0.55 & 0.55 & 0.55 & 0.55 \\
\hline $\mathrm{Ca}(\%)$ & 0.80 & 0.80 & 0.80 & 0.80 \\
\hline $\mathrm{P}(\%)$ & 0.64 & 0.64 & 0.64 & 0.64 \\
\hline
\end{tabular}

1)Provided per $\mathrm{kg}$ of complete diet: 12,000 IU of vitamin A; $2,500 \mathrm{IU}$ of vitamin $\mathrm{D}_{3} ; 25 \mathrm{mg}$ of vitamin $\mathrm{E} ; 0.7 \mathrm{mg}$ of vitamin $\mathrm{K}_{3} ; 1 \mathrm{mg}$ of thiamin, $12 \mathrm{mg}$ of riboflavin; $2 \mathrm{mg}$ of pyridoxine; 0.03 $\mathrm{mg}$ of vitamin $\mathrm{B}_{12} ; 35 \mathrm{mg}$ of niacin; $10 \mathrm{mg}$ of Ca-pantothenate; $0.5 \mathrm{mg}$ of folic acid and $0.085 \mathrm{mg}$ of biotin; $1,700 \mathrm{mg}$ of ethoxyquin.

${ }^{2)}$ Provided per kg of complete diet: 35 mg, Fe; 60 mg, Zn; 85 mg, Mn; 70 mg, Cu; 1.6 mg l; 0.1 mg, Se.

$\mathrm{CON}$, basal diet; $\mathrm{T} 1$, replacing $0.5 \%$ soybean meal with perilla seed meal; $\mathrm{T} 2$, replacing $1 \%$ soybean meal with perilla seed meal; $\mathrm{T} 3$, replacing $2 \%$ soybean meal with perilla seed meal; $\mathrm{ME}$, metabolizable energy; $\mathrm{CP}$, crude protein. 
Table 3. Ingredient composition of finishing diets (2-5 weeks)

\begin{tabular}{|c|c|c|c|c|}
\hline Items & CON & T1 & T2 & T3 \\
\hline \multicolumn{5}{|l|}{ Ingredients (\%) } \\
\hline Corn & 57.75 & 57.65 & 57.55 & 57.445 \\
\hline Soybean meal, $48 \% \mathrm{CP}$ & 28.00 & 27.50 & 27.00 & 26.00 \\
\hline Wheat & 10.00 & 10.00 & 10.00 & 10.00 \\
\hline Corn gluten meal, $60 \% \mathrm{CP}$ & 0.80 & 0.90 & 1.00 & 1.10 \\
\hline Perilla seed meal & 0.00 & 0.50 & 1.00 & 2.00 \\
\hline L-Lysine & 0.140 & 0.145 & 0.150 & 0.155 \\
\hline DL-Methionine & 0.21 & 0.205 & 0.20 & 0.20 \\
\hline Choline chloride & 0.20 & 0.20 & 0.20 & 0.20 \\
\hline Limestone & 1.00 & 1.00 & 1.00 & 1.00 \\
\hline Dicalcium phosphate & 1.50 & 1.50 & 1.50 & 1.50 \\
\hline Salt & 0.20 & 0.20 & 0.20 & 0.20 \\
\hline Vitamin premix ${ }^{1)}$ & 0.10 & 0.10 & 0.10 & 0.10 \\
\hline Mineral premix ${ }^{2)}$ & 0.10 & 0.10 & 0.10 & 0.10 \\
\hline \multicolumn{5}{|l|}{ Calculated composition } \\
\hline $\mathrm{ME}(\mathrm{kcal} / \mathrm{kg})$ & 3,283 & 3,280 & 3,278 & 3,273 \\
\hline $\mathrm{CP}(\%)$ & 20.04 & 20.05 & 20.05 & 20.03 \\
\hline Lysine (\%) & 1.151 & 1.153 & 1.154 & 1.152 \\
\hline Methionine (\%) & 0.527 & 0.526 & 0.524 & 0.525 \\
\hline $\mathrm{Ca}(\%)$ & 0.80 & 0.80 & 0.80 & 0.80 \\
\hline $\mathrm{P}(\%)$ & 0.64 & 0.64 & 0.64 & 0.64 \\
\hline
\end{tabular}

1)Provided per $\mathrm{kg}$ of complete diet: 12,000 IU of vitamin $\mathrm{A} ; 2,500 \mathrm{IU}$ of vitamin $\mathrm{D}_{3} ; 25 \mathrm{mg}$ of vitamin $\mathrm{E} ; 0.7 \mathrm{mg}$ of vitamin $\mathrm{K}_{3} ; 1 \mathrm{mg}$ of thiamin, $12 \mathrm{mg}$ of riboflavin; $2 \mathrm{mg}$ of pyridoxine; 0.03 $\mathrm{mg}$ of vitamin $\mathrm{B}_{12} ; 35 \mathrm{mg}$ of niacin; $10 \mathrm{mg}$ of Ca-pantothenate; $0.5 \mathrm{mg}$ of folic acid and $0.085 \mathrm{mg}$ of biotin; $1,700 \mathrm{mg}$ of ethoxyquin.

${ }^{2)}$ Provided per kg of complete diet: $35 \mathrm{mg}$, Fe; $60 \mathrm{mg}$, Zn; $85 \mathrm{mg}, \mathrm{Mn} ; 70 \mathrm{mg}$, Cu; $1.6 \mathrm{mg} \mathrm{l;} 0.1 \mathrm{mg}$, Se.

$\mathrm{CON}$, basal diet; $\mathrm{T} 1$, replacing $0.5 \%$ soybean meal with perilla seed meal; $\mathrm{T} 2$, replacing $1 \%$ soybean meal with perilla seed meal; $\mathrm{T} 3$, replacing $2 \%$ soybean meal with perilla seed meal; $\mathrm{ME}$, metabolizable energy; $\mathrm{CP}$, crude protein.

\section{Fatty acids composition}

Lipids were analyzed from thigh meat according to the method of Folch et al. [16]. Thigh meat (30 g) was blended with $150 \mathrm{~mL}$ of solution (chloroform : methanol $=2: 1$ ) and added $0.88 \% \mathrm{KOH}$. The solution was kept at room temperature for 2 hours and the upper phase was extracted. Then chloroform was evaporated using $99.9 \% \mathrm{~N}_{2}$ gas and cooling. $1 \mathrm{~mL}$ of BF3-Methanol (Sigma Chemical, St. Louis, MO, USA) was added to the sample and heated at $70^{\circ} \mathrm{C}$ for $30 \mathrm{~min}$. After samples were cooled, $2 \mathrm{~mL}$ of Hexan (HPLC grade) and $5 \mathrm{~mL}$ of distilled water were added to the solution. The upper phase is rolled out after vortexing the samples. Fatty acid methyl ester dissolved in hexane was transferred to a GC vial and the fatty acids were analyzed using a capillary column ( $30 \mathrm{~mm} \times$ $0.32 \mathrm{~mm} \times 0.25 \mu \mathrm{m}$ film thickness, Omegawax 320, Supelco, Bellefonte, PA, USA) of GC (Shimadzu Gas Chromatography 17-A, Tokyo, Japan).

The oven temperature was set to $200^{\circ} \mathrm{C}$ and helium was divided by a $100: 1$ split ratio to serce as a carrier gas at linear flow of $0.79 \mathrm{~mL} / \mathrm{min}$. Fatty acids were determined by comparison with standard retention times and the relative amounts were identicated in weight percent of total fatty acids.

\section{Statistical analysis}

All data were subjected to statistical analysis as a randomized complete block design using GLM procedures of SAS version 9.4 (SAS Inst., Cary, NC, USA). Differences in means among treatment groups were determined using Duncan's multiple range test with a $p<0.05$ indicating statistical significance. 


\section{RESULTS}

\section{Growth performance}

At 2 and 5 weeks, broilers fed with T2 or T3 had significantly $(p<0.05)$ higher BW than broilers fed with CON or T1 (Table 4). From 0 to 2 weeks, WG of broilers fed with T2 or T3 diet was increased $(p<0.05)$ compared to that of broilers fed with CON or T1 diet. Moreover, broilers in T2 treatment group had significantly $(p<0.05)$ higher WG than those fed with T3. FCR was significantly $(p<0.05)$ decreased for broilers fed with T2 or T3 diet. There was no significant difference in FI among groups. From 2 to 5 weeks, WG of broilers fed with T2 or T3 diet was increased. Regarding FI, broilers fed with T1 or T3 had significantly higher FI than those fed with T2 or CON. FCR was significantly increased for broilers fed with $\mathrm{T} 1$ or $\mathrm{T} 2$ diet.

In the overall period, broilers fed with T2 or T3 diet had significantly $(p<0.05)$ higher WG than broilers fed with CON or T1 diet. FI was increased $(p<0.05)$ for broilers fed with T3 diet while broilers fed with T2 diet had lower $(p<0.05)$ FI than those in other treatment groups. FCR was significantly decreased in broilers fed with $\mathrm{T} 2$ diet.

\section{Proximate composition}

There was no significant $(p>0.05)$ difference in moisture or ash composition of breast meat from broilers (Table 5). However, broilers fed with T2 or T3 diet had higher $(p<0.05)$ fat composition in breast meat than broilers fed with $\mathrm{CON}$ or $\mathrm{T} 1$ diet.

\section{Meat quality}

WHC was significantly $(p<0.05)$ increased in broilers fed with T2 or T3 diet (Table 6). However, there was no significant difference in other characteristics among groups.

Table 4. Effects of replacing soybean meal with perilla seed meal on growth performance of ROSS 308 broilers

\begin{tabular}{|c|c|c|c|c|c|c|}
\hline Item & CON & T1 & T2 & T3 & SE & $p$-value \\
\hline \multicolumn{7}{|l|}{ Body weight (g) } \\
\hline Initial BW & 44.60 & 45.00 & 44.60 & 45.00 & 0.02 & - \\
\hline 2 wks & $194.33^{b}$ & $190.67^{b}$ & $203.67^{a}$ & $200.00^{a}$ & 2.21 & 0.031 \\
\hline 5 wks & $1,208.67^{b}$ & $1,205.67^{b}$ & $1,258.00^{\mathrm{a}}$ & $1,256.00^{a}$ & 13.51 & 0.028 \\
\hline \multicolumn{7}{|l|}{ Week 0-2 } \\
\hline Weight gain (g) & $149.73^{c}$ & $145.67^{c}$ & $159.07^{\mathrm{a}}$ & $155.00^{\mathrm{b}}$ & 4.35 & 0.036 \\
\hline Feed intake (g) & 258.20 & 259.67 & 258.33 & 258.33 & 1.41 & 0.854 \\
\hline Feed conversion ratio $(\mathrm{g} / \mathrm{g})$ & $1.72^{\mathrm{b}}$ & $1.78^{\mathrm{a}}$ & $1.62^{c}$ & $1.67^{\mathrm{c}}$ & 0.07 & 0.037 \\
\hline \multicolumn{7}{|l|}{ Week 2-5 } \\
\hline Weight gain (g) & $1,014.33^{b}$ & $1,015.00^{b}$ & $1,054.33^{\mathrm{a}}$ & $1,060.22^{\mathrm{a}}$ & 8.43 & 0.043 \\
\hline Feed intake (g) & $1,717.33^{\mathrm{c}}$ & $1,777.00^{\mathrm{a}}$ & $1,735.33^{b}$ & $1,829.33^{\mathrm{a}}$ & 10.24 & 0.041 \\
\hline Feed conversion ratio $(\mathrm{g} / \mathrm{g})$ & $1.69^{b}$ & $1.74^{\mathrm{a}}$ & $1.65^{\mathrm{b}}$ & $1.73^{\mathrm{a}}$ & 0.04 & 0.048 \\
\hline \multicolumn{7}{|l|}{ Week 0-5 } \\
\hline Weight gain (g) & $1,164.07^{b}$ & $1,160.67^{b}$ & $1,213.40^{\mathrm{a}}$ & $1,215.22^{\mathrm{a}}$ & 14.87 & 0.025 \\
\hline Feed intake (g) & $1,975.53^{\mathrm{c}}$ & $2,036.67^{b}$ & $1,893.67^{d}$ & $2,087.67^{a}$ & 23.41 & 0.033 \\
\hline Feed conversion ratio $(\mathrm{g} / \mathrm{g})$ & $1.72^{\mathrm{a}}$ & $1.76^{\mathrm{a}}$ & $1.67^{\mathrm{b}}$ & $1.73^{\mathrm{a}}$ & 0.04 & 0.018 \\
\hline
\end{tabular}

${ }^{a-d}$ Means in the same row with different superscripts differ $(p<0.05)$.

CON, basal diet; $\mathrm{T} 1$, replacing $0.5 \%$ soybean meal with perilla seed meal; T2, replacing $1 \%$ soybean meal with perilla seed meal; T3, replacing $2 \%$ soybean meal with perilla seed meal; SE, standard error. 
Table 5. Effects of replacing soybean meal with perilla seed meal on proximate composition (\%) of breast meat from ROSS 308 broilers

\begin{tabular}{llllllr}
\hline & Item (\%) & CON & T1 & T2 & T3 & SE \\
\hline Moisture & 75.9 & 75.9 & 74.9 & 75.5 & 1.1 & 0.613 \\
Fat & $1.53^{\mathrm{b}}$ & $1.55^{\mathrm{b}}$ & $1.75^{\mathrm{a}}$ & $1.74^{\mathrm{a}}$ & 0.05 & 0.025 \\
Ash & 1.99 & 2.11 & 2.14 & 1.88 & 0.19 & 0.349 \\
\hline
\end{tabular}

a,b Means in the same row with different superscripts differ $(p<0.05)$.

CON, basal diet; $\mathrm{T} 1$, replacing $0.5 \%$ soybean meal with perilla seed meal; $\mathrm{T} 2$, replacing $1 \%$ soybean meal with perilla seed meal; $\mathrm{T} 3$, replacing $2 \%$ soybean meal with perilla seed meal; SE, standard error.

Table 6. Effects of replacing soybean meal with perilla seed meal on meat quality in ROSS 308 broilers

\begin{tabular}{|c|c|c|c|c|c|c|}
\hline Item & CON & T1 & T2 & T3 & SE & $p$-value \\
\hline WHC (\%) & $63.2^{b}$ & $63.7^{\mathrm{b}}$ & $65.6^{a}$ & $65.8^{\mathrm{a}}$ & 0.8 & 0.033 \\
\hline $\mathrm{pH}$ & 5.88 & 5.97 & 5.93 & 5.90 & 0.07 & 0.335 \\
\hline Drip loss (\%) & 3.14 & 3.28 & 3.18 & 3.11 & 0.14 & 0.486 \\
\hline Cooking loss (\%) & 14.94 & 15.63 & 14.52 & 15.02 & 1.30 & 0.508 \\
\hline Shear force $(\mathrm{g} / \mathrm{g})$ & 2,245 & 2,335 & 2,263 & 2,332 & 57.00 & 0.222 \\
\hline \multicolumn{7}{|l|}{ Meat Color } \\
\hline$L^{*}$, Lightness & 45.8 & 45.3 & 44.9 & 46.4 & 2.0 & 0.775 \\
\hline$a^{*}$, redness & 3.47 & 3.54 & 3.69 & 3.98 & 0.3 & 0.668 \\
\hline$b^{*}$, yellowness & 10.21 & 11.76 & 12.25 & 11.89 & 1.3 & 0.503 \\
\hline
\end{tabular}

a,beans in the same row with different superscripts differ $(p<0.05)$.

CON, basal diet; $\mathrm{T} 1$, replacing $0.5 \%$ soybean meal with perilla seed meal; $\mathrm{T} 2$, replacing $1 \%$ soybean meal with perilla seed meal; $\mathrm{T} 3$, replacing $2 \%$ soybean meal with perilla seed meal; S.E, standard error; WHC, water holding capacity.

Fatty acids composition of thigh meat

Regarding fatty acids composition of thigh meat from broilers, linolenic acid content was increased $(p$ $<0.05$ ) in broilers fed with T3 diet (Table 7).

Table 7. Effects of replacing soybean meal with perilla seed meal on fatty acids composition of thigh meat produced from ROSS 308 broilers

\begin{tabular}{|c|c|c|c|c|c|c|}
\hline Item (\%) & CON & T1 & T2 & T3 & SE & $p$-value \\
\hline Myristic acid (C14:0) & 0.84 & 0.80 & 0.80 & 0.80 & 0.01 & 0.068 \\
\hline Palmitic acid (C16:0) & 18.42 & 18.87 & 18.35 & 18.22 & 0.38 & 0.678 \\
\hline Stearic acid (C18:0) & 6.75 & 6.81 & 6.60 & 6.44 & 0.24 & 0.698 \\
\hline Oleic acid (C18:1n9) & 44.42 & 44.42 & 44.48 & 44.40 & 0.45 & 0.991 \\
\hline Linolenic acid (C18:3n3) & $6.64^{\mathrm{c}}$ & $6.77^{\mathrm{bc}}$ & $6.98^{b}$ & $7.55^{\mathrm{a}}$ & 0.04 & 0.001 \\
\hline Eicosenoic acid (C20:1n9) & 0.35 & 0.34 & 0.34 & 0.37 & 0.02 & 0.659 \\
\hline Arachidonic acid (C20:4n6) & 0.92 & 0.58 & 0.52 & 0.51 & 0.16 & 0.354 \\
\hline Saturated fatty acid & 31.02 & 31.48 & 30.74 & 30.45 & 0.46 & 0.513 \\
\hline
\end{tabular}

${ }^{\mathrm{a}-\mathrm{c}}$ Means in the same row with different superscripts differ $(p<0.05)$.

$\mathrm{CON}$, basal diet; $\mathrm{T} 1$, replacing $0.5 \%$ soybean meal with perilla seed meal; $\mathrm{T} 2$, replacing $1 \%$ soybean meal with perilla seed meal; $\mathrm{T} 3$, replacing $2 \%$ soybean meal with perilla seed meal; SE, standard error. 


\section{DISCUSSION}

In the present study, PSM showed potential as an alternative feedstuff for soybean meal. Moreover, it improved growth performance of broilers. In particular, FCR and WG were significantly increased when 1\%-2\% soybean meal was replaced by PSM. Perilla is a rich source of polyunsaturated fatty acids such as omega-6-fatty acids and omega-9-fatty acids ( $\omega-9)$. It can be the best feedstuff for additional omega-3 polyunsaturated fatty acids [17]. Omega-3-fatty acids ( $\omega-3)$ are a series of fatty acids, including eicosapentaenoic acid (EPA), $\alpha$-linolenic acid, and docosahexaenoic acid (DHA) [18]. Shin et al. [19] have found that supplementation $\omega-3$ and $\omega-9$ fatty acid blends does not affect the accumulation of liver fat or the ratio of live weight to broiler liver weight. However, unlike results of our study, Oh et al. [20] have reported that supplementation of 10\% PSM to 45-d Korean native chickens does not affect the growth performance in a 21-day experiment period. In addition, many studies have found that $\omega-3$ and $\omega$-9-enriched feedstuffs (full-fat flaxseed meal, canola seed meal, fish oil, etc.) do not affect the growth performance of broilers [19-23], although some studies have shown that sesame meal can replace soybean meal to improve the growth performance of broilers [24,25]. More research is needed to determine whether a seed meal is suitable for broiler diets. Based on results of this study, we can see a lot of potential of replacing soybean meal with PSM.

Regarding proximate composition of breast meat from broiler, many researchers have reported that increase of fat content in broilers is associated with the composition of dietary fatty acids. Hadi [26] have reported that 5\% PSM supplementation in duck diet can improve the fat content of meat. Similarly, the supplementation of $\omega-3$ and $\omega-9$ in diet can improve the fat composition of breast meat in broiler $[4,21,23,27,28]$.

In present study, the $\mathrm{pH}$ of the breast meat from broiler fed with PSM as a replacement was not significantly affected by such replacement. However, water holding capacity was significantly increased after soybean meal was replaced with PSM at 1\% or 2\%. Huff-Lonergan and Lonergan [29] and Jung et al. [30] have reported that WHC could be inactivated by oxidation not only by $\mathrm{pH}$, but also by post-protein degradation initiated by the activation of $\mu$-capain. In the current study, the antioxidative effect was not tested, although the substitution of PSM could improve breast meat quality of broilers.

Based on results of fatty acids composition of meat analysis in this study, the content of linolenic acid was increased after soybean meal was replaced with PSM at $1 \%$ or $2 \%$. Such results are similar to previous studies showing that higher percentage of $\omega-3$ can improve meat quality [23,31]. Hulan et al. [4] have reported that $\omega-3$ in broiler meat can be improved by increasing levels of $\omega-3$ in broiler diets. Feeding fat or vegetable seeds containing $\alpha$-LNA can increase the absorption of linolenic acids, EPA, and DHA in poultry and chick tissues [32,33]. Oh et al. [20] have reported that the ratio of $\alpha$-LNA in broiler's breast meat is increased more than three times in 10\% PSM supplementation treatment compared to basal diet. Thus, PSM could be used as a feedstuff for the production of polyunsaturated fatty acid-enriched poultry meat.

\section{CONCLUSION}

Perilla seed meal can improve the growth performance and meat quality when it is used as an alternative of soybean meal in broiler feed. In addition, it can increase linolenic acid content in breast meat. Thus, it may be useful as a replacement for soybean meal. 


\section{REFERENCES}

1. Bang HO, Dyerberg J, Hjørne N. The composition of food consumed by Greenland Eskimos. Acta Med Scand. 1976;200:69-73.

2. Yamori $Y$, Nara $Y$, Iritani N, Workman RJ, Inagami T. Comparison of serum phospholipid fatty acids among fishing and farming Japanese populations and American Inlanders. J Nutr Sci Vitaminol. 1985;31:417-22.

3. Stadelman WJ, Pratt DE. Factors influencing composition of the hen's egg. Worlds Poult Sci J. 1989;45:247-66.

4. Hulan HW, Ackman RG, Ratnayake WMN, Proudfoot FG. Omega-3 fatty acid levels and performance of broiler chickens fed redfish meal or redfish oil. Can J Anim Sci. 1988;68:53347.

5. Hulan HW, Ackman RG, Ratnayake WMN, Proudfoot FG. Omega-3 fatty acid levels and general performance of commercial broilers fed practical levels of redfish meal. Poult Sci. 1989;68:153-62.

6. Al Harthi MA, El Deek AA. Evaluation of sesame meal replacement in broiler diets with phytase and probiotic supplementation. Egypt Poult Sci . 2009;29:99-125.

7. Jacob JP, Mitaru BN, Mbugua PN, Blair R. The feeding value of Kenyan sorghum, sunflower seed cake and sesame seed cake for broilers and layers. Anim Feed Sci Tech. 1996;61:41-56.

8. Zhu J, Fu Q. Optimization of ultrasound-assisted extraction process of perilla seed meal proteins. Food Sci Biotechnol. 2012;21:1701-6.

9. Tong B, Liu D. Extraction of tannin and phytic acid from perilla seed meal. China Oils Fats. 2008;9.

10. Longvah T, Deosthale YG. Effect of dehulling, cooking and roasting on the protein quality of Perilla frutescens seed. Food Chem. 1998;63:519-23.

11. Tang JW, Sun H, Yao XH, Wu YF, Wang X, Feng J. Effects of replacement of soybean meal by fermented cottonseed meal on growth performance, serum biochemical parameters and immune function of yellow-feathered broilers. Asian-Australas J Anim Sci. 2012;25:393-400.

12. National Research Council. Nutrient requirements of poultry. 9th ed. Washington, DC: $\mathrm{Na}-$ tional Academies Press; 1994.

13. AOAC [Association of Office Analytical Chemists] International. Official method of analysis of AOAC International. 16th ed. Arlington, VA: AOAC International; 2000.

14. Laakkonen E, Wellington GH, Sherbon JN. Low-temperature, long-time heating of bovine muscle 1. Changes in tenderness, water-binding capacity, $\mathrm{pH}$ and amount of water-soluble components.J Food Sci. 1970;35:175-7.

15. Sirri F, Petracci M, Zampiga M, Meluzzi A. Effect of EU electrical stunning conditions on breast meat quality of broiler chickens. Poult Sci. 2017;96:3000-4.

16. Folch JM, Lee M, Sloane Stanley GH. A simple method for the isolation and purification of total lipides from animal tissues.J Biol Chem. 1957;226:497-509.

17. Asif M. Health effects of omega-3, 6, 9 fatty acids: perilla frutescens is a good example of plant oils. Orient Pharm Exp Med. 2011;11:51-9.

18. Yoo J, Park GH, Sung JS, Song H, Shin SY, Jung WH, et al. Feed additives in broiler diets to produce healthy chickens without in-feed antimicrobial compounds. Korean J Agric Sci. 2014;41:441-53.

19. Shin DK, Choi SH, Cho YM, Park JH. Omega-3 and-9 fatty acid combination effects on broiler chicks to produce chicks with high in omega-3 polyunsaturated fatty acid. Korean J Poult Sci. 2012;39:1-8. 
20. Oh ST, Jhun HK, Park JM, Kim JM, Kang CW, An BK. Effects of dietary sources containing $\omega$-3 fatty acids on the fatty acid composition of meats in Korean native chickens. Korean J Food Sci Anim Resour. 2012;32:476-82.

21. Yan L, Kim IH. Effects of dietary $\omega$-3 fatty acid-enriched microalgae supplementation on growth performance, blood profiles, meat quality, and fatty acid composition of meat in broilers. J Appl Anim Res. 2013;41:392-7.

22. Kamranazad S, Rahimi SH, Karimi TMA. Effect of dietary oil seeds on N-3 fatty acid enrichment, performance parameters and humoral immune response of broiler chickens. Iran J Vet Res. 2009;10:158-65.

23. Mandal GP, Ghosh TK, Patra AK. Effect of different dietary n-6 to n-3 fatty acid ratios on the performance and fatty acid composition in muscles of broiler chickens. Asian-Australas J Anim Sci. 2014;27:1608-14.

24. Rama Rao SV, Raju MVLN, Panda AK, Poonam NS, Sunder GS, Sharma RP. Utilisation of sesame (Sesamum indicum) seed meal in broiler chicken diets. Br Poult Sci. 2008;49:81-5.

25. Al Harthi MA, El Deek AA. Evaluation of sesame meal replacement in broiler diets with phytase and probiotic supplementation. Egypt Poult Sci J. 2009;29:99-125.

26. Hadi RF. Effect of dietary supplementation of frutescens seeds (Perilla frutescens L.) on growth performance, slaughter weight, carcass weight, and meat quality of male local duck. IOP Conf Ser Mater Sci Eng. 2019;633:012013.

27. Ferrini G, Baucells MD, Esteve-Garcia E, Barroeta AC. Dietary polyunsaturated fat reduces skin fat as well as abdominal fat in broiler chickens. Poult Sci. 2008;87:528-35.

28. Chekani-Azar S, Shahriar HA, Maheri-Sis N, Ahmadzadeh AR, Vahdatpoor T. Omega-3 fatty acids enrichment and organoleptic characteristics of broiler meat. Asian J Anim Vet Adv. 2008;3:62-9.

29. Huff-Lonergan E, Lonergan SM. Mechanisms of water-holding capacity of meat: the role of postmortem biochemical and structural changes. Meat Sci. 2005;71:194-204.

30. Jung S, Choe JH, Kim B, Yun H, Kruk ZA, Jo C. Effect of dietary mixture of gallic acid and linoleic acid on antioxidative potential and quality of breast meat from broilers. Meat Sci. 2010;86:520-6.

31. Zuidhof MJ, Betti M, Korver DR, Hernandez FI, Schneider BL, Carney VL, et al. Omega-3-enriched broiler meat: 1. optimization of a production system. Poult Sci. 2009; 88:110820.

32. Ajuyah AO, Lee KH, Hardin RT, Sim JS. Changes in the yield and in the fatty acid composition of whole carcass and selected meat portions of broiler chickens fed full-fat oil seeds. Poult Sci. 1991;70:2304-14.

33. Phetteplace HW, Watkins BA. Effects of various $n-3$ lipid sources on fatty acid compositions in chicken tissues. J Food Compost Anal. 1989;2:104-17. 